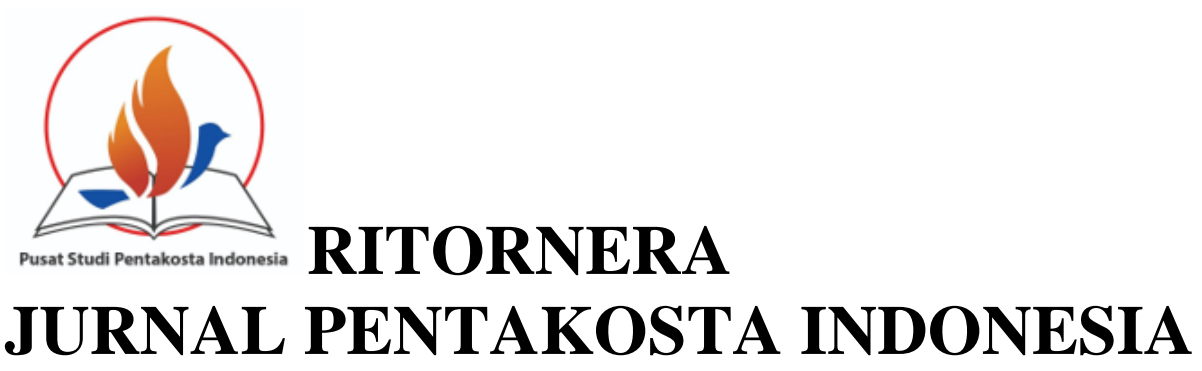

Vol. 1, No. 3, Desember 2021

Available at: pspindonesia.org

\title{
Membaca Pemikiran Ulrich Zwingli Tentang Reformasi Gereja (Sebuah Penelusuran Sejarah Gereja Hingga Sekarang ini)
}

\author{
Hery Budi Yosef 1 \\ herybudiyosef@gmail.com
}

\begin{abstract}
This journal examines the historical description of Ulrich Zwingli's thoughts on church reform, especially after Martin Luther. And the results of the research provide new thinking that was left behind towards the reforms at that time. Though doctrinal thought began to move away from the papal hierarchy, but there are still things that were maintained by the reformers, and until now in the modern era it seems to be running (held), namely the practice of infant baptism, and the concept of the relationship between church and state. It's just that the results of this research are not more there, because the focus is solely on searching. There are many other sources that review Zwingli's actions in his involvement in removing other groups of believers (read: Anabaptists) from the church decisions that he fought for after the reformation. Because the concrete evidence has not shown the accuracy of the event, the author only focuses on his thoughts, specifically confronting his thoughts with the previous proclaimer of reform, namely Martin Luther. In this study, the background of the character, Zwingli's movement in Switzerland in an effort to reform the church will also be described successively as an extension of the previous important figures. In another section, Zwingli's thoughts which are the reasons for the reform of the church will be presented, Zwingli is slightly different from his predecessors in post-reform theology from Luther's. This journal uses a descriptive-historical qualitative approach, it is said that because the author examines it by tracing the sources contained in the literature regarding the characters studied, and linking them to the church today. Of course, there will be limitations in the study, that's why the author hopes that there will be further research on this church figure, especially in other studies.
\end{abstract}

Keywords: Reformation, Church, Theology, History.

\section{Abstrak}

Jurnal ini mengkaji uraian historis terhadap pemikiran Ulrich Zwingli mengenai reformasi gereja khususnya setelah Martin Luther. Dan hasil dari penelitian memberikan pemikiran baru yang tertinggal terhadap reformasi kala itu. Pemikiran secara doktrinal yang mulai menjauh dari kehirarkian kepausan, namun masih ada hal yang dipertahankan oleh para reformator, dan hingga kini di era modern terlihat berjalan (diadakan), yakni praktik baptisan bayi, dan konsep hubungan gereja dan negara. Hanya saja hasil penelitian ini tidak lebih banyak ke sana, karena fokus kepada penelusuran semata. Lainnya banyak 
sumber yang mengulas tentang sepak terjang Zwingli dalam keterlibatannya menyingkirkan kelompok orang percaya lainnya (baca: Anabaptis) dari ketetapan gereja yang diperjuangkannya pasca reformasi. Oleh sebab bukti-bukti konkrit belum menunjukkan keakuratan terhadap pristiwa tersebut, penulis hanya menyoroti pemikiran-pemikirannya, secara khusus mengkonfrontasikan pemikirannya dengan proklamator reformasi sebelumnya, yakni Martin Luther. Dalam kajian ini juga akan dipaparkan secara berturutturut tentang latar belakang tokoh, pergerakan Zwingli di Swiss dalam upaya pembaharuan gereja sebagai perluasan dari tokoh-tokoh penting sebelumnya. Di bagian lain pemikiranpemikiran Zwingli yang menjadi alasan reformasi gereja akan dipaparkan, Zwingli sedikit berbeda dengan pendahulunya dalam berteologi di pasca reformasi dengan yang dikemas oleh Luther. Jurnal ini menggunakan pendekatan kualitatif deskritif - historis, dikatakan demikian karena penulis mengkaji dengan menelusuri sumber-sumber yang terdapat di literatur mengenai tokoh yang diteliti, dan mengkaitkan kepada gereja di masa kini. Tentunya akan ada keterbatasan dalam pengkajiannya, itu sebabnya penulis berharap akan ada penelitian lanjut terhadap tokoh gereja ini, khususnya dalam kajian yang lain.

Kata kunci : Reformasi, Gereja, Teologi, Sejarah

${ }^{1}$ STT Global Glow Indonesia

\section{PENDAHULUAN}

Ulrich Zwingli dilahirkan di sebuah desa yang bernma Widhaus, di lembah Toggenberg, Switzerland (Swiss), pada tanggal 1 Januari 1484. Ayahnya seorang pemuka atau burgermeister (Mayor) dilingkungan desanya, dan ibunya adalah saudara perempuan dari seorang imam, ia memiliki tujuh saudara laki-laki dan dua orang saudara perempuan. Zwingli dididik dalam keluarga Katolik Roma yang taat. Pada usia 5 tahun, ia tinggal bersama pamannya Bartolomew seorang Imam wilayah di Wesen. Mulai pada usianya yang ke 10 tahun Zwingli dikirim ke Basel untuk belajar pada sekolah Latin, ia belajar bahasa Latin, Musik dan Dialekta. Lalu di usianya ke 14 tahun, ia masuk Kolose Bern yang diampu oleh sarjana klasik Swiss Heinrich Wolfin, di Bern ia dididik dengan pengaruh Monastic Dominican. Dua tahun kemudian ia belajar di Universitas Wina untuk mempelajari filsafat skolastik, astronomi dan fisika. Ia ingin menjadi humanis. Pada usia 22 tahun ia memperoleh gelar MA, dan diangkat sebagai Imam di daerah Glarus sebuah kota kecil yang berjarak 30 mil dari Zurich (Gonzalez, 46-47, 1985). Di Glarus ini ia banyak menentang praktek perdagangan tentara bayaran, yang menurutnya perbuatan tidak bermoral, karena banyak orang-orang muda mati menjadi tentara bayaran untuk membela kepentingan bangsa lain. Ia menyaksikan sendiri dalam tiga peretempuran yang ia ikuti karena ia menjadi chaplain (Imam khusus tentara) dalam pertempuran-pertempuran tersebut. Dalam peperangan antara Perancis melawan Paus Julius II dan Leo X itu, tercatat ada sepuluh ribu 
tentara Swiss yang gugur. Pahamnya yang menentang penjualan tentara bayaran banyak dipengaruhi oleh Erasmus. Walaupun ditengah-tengah kesibukannya, Zwingli menyempatkan diri memperlajari di perpustakaan ajaran-ajaran bapa gereja seperti Origen, Jerome, Augustine.

Karena banyak yang tidak menyukainya, maka pada tahun 1516 saat ia berusia 32 tahun, ia pindah menjadi Imam di wilayah Einsiedeln. Namun di Einsiedeln inipun, ia banyak menemukan masalah terutama dengan penyembahan berhala kepada Virgin of Meinrad (Black Virgin), suatu sinkretisme antara kepercayaan agama nenek moyang setempat dengan agama Katolik. Di sini ia masih terus melanjutkan studi pribadinya dengan mempelajari tulisan-tulisan Bapa-bapa Gereja seperti Origenes, Ambrosius, Chrysostomos, Augustinus dan lain-lain. Ia mulai menyerang dan menentang penjualan suarat Indulgensia, kesewenang-wenangan paus dan praktek-praktek gereja yang salah (Sasongko, Jurnal Veritas 2004), Zwingli pun mengajak umat untuk menyembah Yesus saja dan bukan menyembah Maria atau orang-orang Kudus (tradisi kepausan saat itu).

Pada tahun 1518 Zwingli diangkat sebagai Imam di kota Zurich yang merupakan kota besar di negara federasi Swiss, di kota inilah ia memulai perjuangan reformasinya sehingga pengaruhnya menyebar di seluruh dataran Eropa. Dua tahun pertama perjuangan reformasinya tidak mengalami hambatan, namun tahun-tahun berikutnya ia mulai dihambat oleh Paus, tahun 1523 ia mendapat teguran dari Paus. Setahun sebelumnya di tahun 1522, Zwingli bersama 10 imam lainnya mengirim surat petisi kepada paus untuk diberi kebebasan mengajarkan Injil, namun surat itu ditolak. Karena ditolak, perlawanan terhadap Paus semakin terbuka dengan pernyataan darinya bersama para imam untuk menikah, Zwingli menikah tahun 1522 dengan Anna Reinhart. Atas persetujuan dewan kota Zurich, Zwingli mendapatkan kebebasan menjalankan reformasinya, setelah berhasil di Zurich ia mengajak seluruh provinsi di Swiss untuk bergabung bersamanya untuk mencapai cita-citanya mendirikan negara Swiss yang Injili. Tetapi provinsi-provinsi yang masih menganut Katholik menolak dan segera membuat aliansi tandingan untuk melawan kelompok Zwingli, akibatnya terjadilah perang di antara mereka pada tahun 1529, dan terjadi lagi perang kedua kalinya pada tahun 1531 yang mengakibatkan gugurnya Zwingli dalam peperangan tersebut. Tepatnya tanggal 11 Oktober 1531 Zwingli meninggal di kota Kapel.

\section{METODE}

Jurnal ini menggunakan pendekatan kualitatif deskritif historis, dikatakan demikian karena penulis mengkaji dengan menelusuri sumber-sumber yang terdapat di literatur 
mengenai tokoh yang diteliti, dan mengkaitkan kepada gereja di masa kini. Tentunya akan ada keterbatasan dalam pengkajiannya, itu sebabnya penulis berharap akan ada penelitian lanjut terhadap tokoh gereja ini, khususnya dalam kajian yang lain.

\section{HASIL DAN PEMBAHASAN}

\section{Reformasi di Swiss yang Diprakarsai oleh Zwingli}

Banyak buku yang menulis bahwa titik permulaan dari panggilan Tuhan yang nyata bagi Zwingli secara pribadi, yang akhirnya membuatnya menjadi seorang reformator adalah pengalamannya saat menderita penyakit pes yang berlangsung di Zurich dari Agustus 1519 sampai februari 1520, telah membunuh satu dari empat penduduk. Pelayanan penggembalaan Zwingli yang mencakup penghiburan terhadap orang-orang yang hampir meninggal, sehingga menyebabkan ia tertular penyakit tersebut. Saat ia berada diantara krisis antar hidup dan mati, ia menyadari bahwa ajal seseorang hanya dapat ditentukan oleh Tuhan. Ia tidak dapat berharap pertolongan pada para Santo (orang-orang kudus), atau berharap pada pengampunan gereja untuk dosa-dosanya. Sebagai refleksi bahwa ia lebih berharap pada Tuhan dari pada yang lainnya, ia menulis syair yang dikenal sebagai Peslied atau "Nyanyian Pes" didalamnya juga nampak ketetapan dan keteguhan hatinya untuk berkomitmen pada Allah. Adapun syairnya adalah sebagai berikut :

\section{Lakukanlah seperti apa yang Engkau kehendaki}

Karena aku tidak kekurangan suatu apa

Aku adalah bejana-Mu

\section{Untuk dibentuk kembali dan dihancurkan ${ }^{1}$}

Setelah ia mengalami kesembuhan, ia terus melakukan aktivitas reformasinya, strategi yang ia lakukan dimulai melalui khotbah-khotbahnya di jemaatnya. Pada tahun 1520 ia mengkhotbahkan pada jemaatnya eksposisi Injil Matius, dan Kitab Kisah Para Rasul, lalu tahun 1521 ia berkhotbah dari I Timotius dan Galatia. Lalu pada tahun 1523 ia beralih ke surat 1 dan 2 Petrus dan Surat Ibrani, lalu ia beralih ke kitab-kitab Injil mulai dari Injil Lukas lalu ke Injil Yohanes. Zwingli tidak beranjak dari PB, hingga akhirnya pada pertengahan tahun 1525, ia mulai mengkhotbahkan PL. ${ }^{2}$

Khotbahnya adalah strategi yang efektif untuk menyatakan pandangan-pandangan reformasinya, khotbahnya yang banyak membahas secara sistematis kitab-kitab Alkitab

\footnotetext{
${ }^{1}$ McGrath, Alister E., Sejarah Pemikiran Reformasi,_Jakarta: BPK Gunung Mulia, 1997, hlm. 156. hlm. 49.

${ }^{2}$ Estep, W.R., The Reformation And Protestantisme, Texas, USA : Carib Baptist Publications, 1983, 
secara keseluruhan merupakan hal yang radikal pada waktu itu, ia berusaha mengangkat kembali peranan utama wewenang Alkitab. ${ }^{3}$ Khotbah-khotbahnya dipenuhi ilustrasi dan humor, walaupun suaranya tidak begitu keras ia mampu membuat jemaat terjaga dan terfokus pada ajaran doktrinnya. Jelas tujuan dari khotbah-khotbahnya ingin mengajarkan Kristus dari sumbernya dan menyatakan Kristus yang sejati dalam hati umat. ${ }^{4}$

Pada tahun 1522 ada dua event yang memberikan indikasi bahwa di bawah kepemimpinan Zwingli, Reformasi Swiss mulai bergulir, event yang pertama dikenal dengan sebutan The Sausage Incident atau "insiden sosis". Pada waktu itu, secara tradisional jemaat seperti biasa menjalankan puasa selama satu kurun waktu, dengan hanya memakan sayur dan ikan, dan tidak diperbolehkan memakan daging. Pengikut-pengikut Zwingli "melanggar" larangan memakan daging tersebut dengan sengaja makan sosis. Zwingli mengajukan argumentasinya mengenai larangan memakan daging pada waktu puasa tidak ada dasarnya. Ia mendasarkan argumentasinya dari ayat-ayat 1 Kor. 8:8, 10:25; Kol. 2:16; 1 Tim. 4;1; dan Roma 14:1-3, 15:1,2. Akibat dari pernyataan argumentasinya, Zwingli mulai mendapat peringatan dari pihak kepausan melalui Uskup dari Constance, Uskup mengirim tim investigasi untuk menyelidiki kejadian di Zurich, Uskup juga menyetujui pertemua Swiss Diet di Baden, yang jaraknya hanya beberapa mil dari Zurich, ia menginginkan pemerintahan kota Zurich memperingatkan Zwingli dan pengikutnya, karena ajaran mereka telah menyimpang dari tata ibadah Katholik Roma.

Setelah mendapat peringatan dari Uskup Constance Zwingli bukannya jera malah menjadi-jadi ingin melakukan reformasi terhadap Roma Katolik, karena ia muak terhadap praktek agama yang menyeleweng dari Firman Tuhan. Justru ketika parlemen Swiss melakukan sidangnya di Baden Zwingli membuat suatu petisi yang diajukan kepada Uskup yang sedang pusing melihat tindakan Zwingli itu. Judul dari dokumen petisi itu sangat panjang yaitu "Petition Of Certain Preachers of Switzerland to the Most Reverend Lor Hugo, Bishop of Constance, that he will not Suffer Himself to be Persuaded to Make any Proclamation to the Injury of the Gospel, nor longer the scandal of harlotry, but Allow The Priest to Marry Wives, or at Least to Wink at theri Marriages”. Artinya: Petisi dari para pengkhotbah Sejati di Swiss untuk yang mulia Tuanku Pastor Hugo, Usckup dari Constance, yang mana ia tidak akan lagi menyengsarakan dirinya sendiri untuk membawanya membuat

${ }^{3}$ Lane, Tony., Runtut Pijar: Sejarah Pemikiran Kristiani, Jakarta: BPK Gunung Mulia, 1993, hlm. 142.

${ }^{4}$ Wellem, F. D., Riwayat Hidup Singkat Tokoh-Tokoh Dalam Sejarah Gereja, Jakarta : BPK Gunung Mulia, hlm 254.

Copyright(C) 2021; Ritornera - Jurnal Teologi Pentakosta Indonesia, ISSN 2797-7676 (online), 2797$717 \mathrm{x}$ (print) $\mid 45$ 
suatu pernyataan yang melukai Injil, dan juga tidak tinggal tetap dalam skandal dengan pelacur, tetapi yang mengijinkan Para Pendeta untuk menikah dengan istri-istrinya, atau setidaknya merasakan pernikahan walau dalam sekejap. Beberapa hari kemudian setelah petisi ini, Zwingli pun menerima surat dari Jerman yang mengalami reformasi juga surat isi surat itu sepaham dengan keinginan Zwingli, yaitu: 'Injil tidak melarang dan tidak ada seeorang pun yang dapat menahan seorang Pendeta menikah karena alasan untuk menghindari dosa perzinahan/skandal". Hal ini tentunya menambah semangat Zwingli.

Petisi yang ditujukan pada Uskup ini, berisi sebelas tanda-tangan termasuk Zwingli, setelah itu Zwingli menikah dengan Anna Rhinehard, yang suami pertamanya mati terbunuh dalam peperangan. Pernikahan ini dinamakan crerical marriage. ${ }^{5}$ Petisi ini dicetak oleh Froscheur dan didistribusikan oleh Zwingli dan teman-temannya.

Negara konfederasi Swiss pada waktu itu terdiri dari pemerintahan-pemerintahan provinsi (canton) dan pemerintahan-pemerintahan kota. Zwingli berada dibawah pemerintahan kota Zurich. Sebagai warga negara kota Zurich, Zwingli menginginkan diadakan debat antara dia dengan pihak Roma Katholik, Zwingli mengundang Uskup untuk datang pada acara debat tersebut, namun Uskup menolak ajaran tersebut dan ia mengitim utusan ke acara perdebatan itu, yakni Johann Fabri sebagai General Vicar. Pada tanggal 29 Januari 1523 dihadapan 600 orang yang hadir, Zwingli berdiri di tengah podium dengan Teks Alkibat berbahasa Ibrani, Yunani, dan Latin. Pertemuan tersebut diadakan di Gedung Balai Kota, para hadirin terdiri dari para Rohaniwan dari kota Zurich dan seluruh Provinsi di Swiss, dan juga seluruh anggota dewan kota, bahkan ketua dewan kota membuka perdebatan antaran Zwingli vs Katholik Roma. Di antara para hadirin mayoritas adalah pendukung Zwingli, sedangkan pihak Katholik hanya didukung oleh sedikit orang saja. Pada saat perdebatan dimulai pihak Khatolik menampik bahwa mereka datang untuk berdebat, mereka datang hanya untuk menginvestigasi dan rekonsiliasi. Fabri sebagai wakil pihak Katholik mengatakan yang dapat menilai Zwingli adalah hasil dari sidang di Nuremberg tahun ini dan atas hasil masukan dari Universitas Paris, Cologne atau Louvain, pihak merekalah yang dapat menghakimi. Lalu Zwingli dapat menanggapi dengan katakata yang dapat memecahkan suasana yaitu: "Mengapa bukan kota Erfurt atau Wuttenburg?" Kata-kata itu disambut gelak tawa hadirin. "Tidak" Jawab Fabri dengan muka kecut. "Luther terlalu dekat dengan kota-kota tersebut, selain itu kejahatan datang dari bagian utara."6 Dalam perdebatan itu Zwingli menunjukkan perlawanannya terhadap Gereja

${ }^{5}$ Estep, W.R, Ibid. hlm. 50.

${ }^{6}$ Estep, W.R, Ibid, hlm. 52-54.

Copyright@2021; Ritornera - Jurnal Teologi Pentakosta Indonesia, ISSN 2797-7676 (online), 2797$717 x$ (print) $\mid 46$ 
Katholik Roma, ia menyerang kesewenang-wenangan paus. Penjualan surat indulgensia, dan kebobrokan lainnya dalam gereja. Ia mengecam Uskup Constance secara langsung karena saat itu ia telah memenjarakan seorang Pendeta dari sebuah desa dekat kota Constance, karena telah mengkhotbahkan doktrin reformasi. Zwingli mengajak juga agar umat tidak mematuhi ajaran yang tidak memiliki dasar Alkitab, misalnya ia menghimbau umat supaya jangan lagi menyembah Maria dan para Santo, sebab hanya Kristus Tuhan yang patut disembah. Pandangannya dirangkum dalam The Sixty-Seven Article atau 67 artikel/dalil. Dewan Kota akhirnya mendukung Zwingli yang menunjukkkan kepiawaiannya dengan mengemukakan thesisnya yang berisi 67 artikel tersebut. Dewan Kota lebih memilih keluar dari kekuasaan Katholik dan ingin berdiri sendiri dalam menjalankan praktek keagamaannya. Kemenangan ada di pihak Zwingli. Zwingli akhirnya menjadi pemimpin reformasi yang diakui di kota Zurich, ia menyetujui prinsip gereja dan pemerintahan harus berjalan bersama-sama menjalankan ajaran Kristus, sehingga tercipta masyarakat Kristiani. Teologia Zwingli yang penting adalah kota dan gereja di Zurich secara efektif merupakan satu, dan merupakan badan yang sama, ${ }^{7}$ teologinya ini akan mempengaruhi cara pandangnya tentang makna gereja dan sakramen. Konsekuensinya pemerintahan (dalam hal ini dewan kota Zurich) berhak mencampuri urusan gereja, bahkan dewan kota juga berhak mengatur tata ibadah gereja, menafsirkan Alkitab, dan praktek-praktek agama lainnya. Dewan kota juga memberikan hukuman kepada warga yang melanggar aturan gereja-kota tersebut. Prinsip ini dikenal sebagai gereja-kota Zurich, stiap warga kota Zurich adalah warga gereja Zurich. Keberhasilan reformasi model ini pun diikuti dengan keberhasilan kota lain seperti Baselm Bern dan puncaknya mempengaruhi kota Jenewa yang membawa keberhasilan dari Reformasi Calvin di tahun 1530-an. Reformasi ini dinamakan Reformasi Magisterial, reformasi yang memeluk/mengajak pemerintah untuk bekerja sama dalam menjalankan reformasi.

\section{Enampuluh Tujuh Dalil yang Dilontarkan Zwingli}

Di bawah ini beberapa kutipandari 67 dalil berikut nomor-nomornya yang dikemukakan Zwingli:

1. Semua orang yang mengatakan Injil tidak berarti apa-apa tanpa pengakuan/penerimaan gereja, sungguh bersalah dan menghina Allah.

\footnotetext{
${ }^{7}$ McGrath, A.E., Ibid, hlm. 200.
} 
2. Inti dari Injil adalah Yesus Kristus Tuhan kita, benar Anak Allah, yang telah meperkenalkan Bapa Surgawi kepada kita dan yang telah menebus kita dari kematian kekal, dan yang telah mendamaikan kita dengan Allah.

3. Hanya Yesus Kristus Jalan Keselamatan bagi semua orang, siapapun dan dimanapun.

4. Siapaun yang mengatakan atau menunjukkan ada "jalan/pintu" lain, ia sungguh bersalah, ia adalah seorang pembunuh jiwa dan seorang perampok.

7. Kristus adalah kepala bagi semua orang percaya yang adalah tubuhNya dan tanpa Dia tubuh itu jadi mati.

8. Semua orang yang tinggal di dalam Dia (kepala) adalah anggota tubuhNya dan adalah anak-anak Allah, itulah Gereja, persekutuan orang-orang Kudus, mempelai Kristus, gereja Chatolica (universal).

15. Siapa yang percaya Injil akan diselamatkan, siapa yang tidak percaya akan dihukum. Dalam Injil seluruh kebenaran dinyatakan dengan jelas.

16. Dari Injil kita belajar bahwa doktrin dan tradisi manusia tidak dapat digunakan untuk memperoleh keselamatan.

17. Kristus adalah satu-satunya Imam Besar Abadi. Siapa yang menganggap dirinya sebagai Imam Besar, berarti salah sebab menentang martabat dan kehormatan Kristus.

18. Kristus hanya sekali mempersembahkan dirinya di kayu salib, itu adalah korban yang cukup bagi semua dosa orang percaya, seingga tidak pernah diulang. Karena itu misa bukan korban tapi peringatan terhadap pengorbanan Yesus di kayu salib, misa adalah tanda penebusan Kristus.

19. Hanya Kristus yang menjadi Pengantara manusia dengan Allah.

20. Kristus adalah kebenaran kita yang menjadi pengantara manusia dengan Allah.

24. Orang Kristen tidak dibatasi dalam melakukan sesuatu yang tidak diperintahkan Kristus, jadi orang Kristen dapat makan kapanpun dan memakan semua jenis makanan.

26. Tidak ada yang paling dibenci Allah kecuali kemunafikan.

27. Semua Kristen adalah bersaudara.

28. Apapun yang diijinkan dan yang tidak dilarang adalah benar. Ini berarti perkawinan dapat dilakukan oleh semua orang.

34. Kuasa Rohani (Hierarki) tidak memiliki dasar Alkitab, maupun pengajaran Yesus.

35. Kuasa dunia (negara) diperjelas dalam pengajaran dan teladan Yesus.

Copyright@(2021; Ritornera - Jurnal Teologi Pentakosta Indonesia, ISSN 2797-7676 (online), 2797$717 x$ (print) $\mid 48$ 
37. -38. Semua orang Kristen wajib mentaati pemerintah; hal itu dibuat bukan sebagai perintah yang menentang Allah.

49. Saya mengetahui tidak ada skandal yang lebih besar daripada hukum yang melarang pernikahan para imam, tetapi demi uang para imam diijinkan memiliki gundik. Sungguh memalukan.

50. Hanya Allah yang berkuasa mengmapuni dosa melalui Yesus Kristus, satu-satunya Tuhan.

57. Kitab suci memberitahukan tidak ada Purgatori setelah hidup ini (kematian).

58. - 59. Hanya Allah yang mengetahui keadaan seseorang yang telah meninggal. Allah hanya sedikit memberitahukan tentang hal itu, maka pengetahuan kita tentnag hal tersebut juga hanya sedikit.

66. Semua pemimpin rohani harus segera bertobat; dan hanya mengikuti salib Kristus, atau mereka akan dihukum. Kapak sudah tersedia pada akar pohon. ${ }^{8}$

1.

Dalam 26 Dalil yang dikutip dari 67 dalil tersebut, nampak pemandangan Zwingli tentang hakikat Injil, Kristologi, Soteriologi, Ekklesiologi, Bibliologi, dan Etika Kristen.

Tidak dapat disangkal lagi bahwa buah dari reformasi adalah mengembalikan lagi Alkitab kepada kedudukannya yang benar. Dalam gereja katolik Roma, kedudukan Alkitab berada di bawah otoritas gereja. Sebagai konsekuensinya yang berhak menentukan tafsiran Alkitab adalah Gereja (Paus). Dalam era reformasi kedudukan paus diturunkan, dan kedudukan Alkitab dinaikkan. Sebagai konsekuensinya gereja harus tunduk kepada Alkitab, Alkitab sebagai yang berwibawa mengatur kehidupan bergereja. ${ }^{9}$

Karya Zwingli yang terkenal mengenai pandangannya terhadap Alkitab adalah Kejelasan dan Kepastian Firman Allah (terbit tahun 1522). Ia mengajukan prinsip Protestan tentang Alkitab yang mempunyai wewenang. Firman Allah adalah pasti. Kalau Allah berbicara, terjadilah, maka pasti terjadi (Kej. 1:3). Firman Allah juga jelas. Namun dalam hal ini tidak berarti bahwa tidak mungkin terjadi salah tafsir. Kalau Allah yang berbicara ketika membaca Alkitab, maka FirmanNya akan membawa kejelasan sendiri, Luther menyebutkan Alkitab dapat menafsirkan dirinya sendiri dengan jelas. Selanjutnya Zwingli mengatakan Roh menerangi kita dan membuat kita mampu mengerti pesan Allah

\footnotetext{
${ }^{8}$ Schaff, Philip., History of The Christian Church, Grand Rapid: Wm. B. Eerdmans Publishing Company, 1958, hlm. 52-53.

${ }^{9}$ Grant, Robert M., Sejarah Singkat Penafsiran Alkitab. Jakarta : BPK Gunung Mulia, 1993, hlm. 102.
} 
sebagaimana yang dimaksudkan-Nya. Kita harus waspada jangan sampai Firman Allah ditaklukan pada tafsiran manusia yang dapat salah, seperti Paus dan konsili. Sekali lagi tafsiran manusia mungkin salah, maka harus berhati-hati. ${ }^{10}$

Bagi para reformator, Alkitab adalah Firman Allah, ada juga yang mengatakan Alkitab memuat Firman Allah tertuama Perjanjian Baru, karena berbicara tentang Kristus. Alkitab yang diterima sebagai Firman Allah adalah kitab-kitab kanonik. Deutoronika dan Apokrifa tidak termasuk kitab suci, tetapi dipandang sebagai tulisan saja yang dapat dibaca untuk memperluas pemahaman. ${ }^{11}$

Zwingli memang dengan jelas mengakui Alkitab sebagai Firman Alah yang berkuasa dan hanya melalui Alkitab kita dapat beriman kepada Allah, namun Zwingli menghadapi permasalahan dalam hal menafsirkan isi Alkitab, prinsip penafsirannya banyak berbeda dengan para reformator lainnya, misalnya dengan marthin Luther. Dalam abad pertengahan metode tafsir Alkitab yang dikenal adalah Quadriga atau "pengertian rangkap empat dari Kitab Suci" yaitu : 1. Pengertian harafiah, 2. Pengertian alegoris, 3. Pengertian Tropologis atau moral, 4. Pengertian anagogis atau futuristik. Luhter menolak metode tafsir model alegoris, tropologis dan anagogis. Ia lebih setuju metode tafsir harfiah namun dengan tambahan/varian yang lebih komples darinya.

Zwingli dalam metode tafsirnya lebih menekankan arti alamiah (wajar) dari Alkitab, yang tidak selalu harus identik dengan arti harfiah. Satu contoh yang dikemukakan oleh Zwingli adalah perkataan Kristus pada Perjamuan Malam. Ketika memecahkan roti, Ia mengucakan kata-kata : 'Inilah tubuhKu" (Mat. 26:26). Arti harafiah dari kata-kata tersebut adalah "pecahan roti ini adalah tubuhKu". Tetapi artinya yang wajar adalah "pecahan roti ini menandakan atau mengartikan tubuhKu". Contoh lain dari metode tafsir yang lain dari Zwingli adalah pernyataannya bahwa cerita Abraham dan Ishak dalam Kejadian 22 memiliki arti yang lebih mendalam. Menurut Zwingli detail-detail dari historis cerita itu mudah sekali dianggap sebagai arti yang sebenarnya, namun nyatanya arti yang sebenarnya (yang lebih mendlam) dari cerita itu hanya dapat dipahami sebagai suatu antisipasi profetis dari cerita tentang Yesus, Abraham mewakili Allah dan Ishak adalah figur (atau, istilah yang lebih teknis tipenya) dari Yesus. Banyak ahli yang mengatakan metode tafsir Zwingli banyak dipengaruhi oleh humanisme, terutama dari Erasmus, yang dalam bukunya Einchiridon mengemukakan perbedaan antara "huruf" dan "roh", artinya kata-kata dari Alkitab dan maknanya merupakan dua hal yang berbeda. Dalam PL khususnya, kata-kata dalam teks

${ }^{10}$ Lane, Toni., Ibid, hlm. 142-143.

${ }^{11}$ McGrath, Alister E., Ibid. 182-183.

Copyright@2021; Ritornera - Jurnal Teologi Pentakosta Indonesia, ISSN 2797-7676 (online), 2797$717 \mathrm{x}$ (print) $\mid 50$ 
seperti kulit yang mengandung - tetapi identik dengan - biji atau inti makna. Arti luaran dari teks sering menyembunyikan makna yang lebih dalam yang tidak terlihat. ${ }^{12}$ McGrath lebih cenderung memasukkan Zwingli ke dalam kelompok humanisme bersama-sama Erasmus dan Brucer yang memiliki metode tafsir moral atau tropologis.

Bagi Zwingli Alkitab menyatakan tuntunan-tuntunan moral yang dibuat Allah untuk orang-orang percaya, dan sebagai petunjuk apa yang harus dilakukan manusia untuk meneladani Kristus. Hal tersebut dikarenakan Zwingli lebih menekankan reformasi sebagai cara untuk mempengaruhi gereja dan masyarakat daripada secara individual. Karena keprihatinan Zwingli terhadap moral dan spiritual kita Zurich, maka reformasinya lebih menekankan nilai-nilai moral, dan Kristus adalah teladan moral yang harus diikuti. ${ }^{13}$

Para reformator memang memiliki keragaman dalam metode tafsirnya, namun belum adanya kesepakatan dalam metode tafsir, mengakibatkan para reformator dihadapkan pada persoalan yang lain yaitu persoalan siapakah yang berhak menafsirkan Alkitab. Pada mulanya Zwingli lebih menekankan hak tafsir individual seperti yang dinyatakannya dalam bukunya Kejelasan dan Kepastian Firman Allah" sebagai berikut: "Firman Allah, segera setelah ia menyinari pengertian seorang individu, meneranginya dengan cara sedemikian rupa sehingga ia memahaminya". Pernyataannya ini menampakkan bahwa seorang individu berhak menafsirkan Alkitab sehingga jelas baginya. Namun lambat laun metode tafsir dari Zwingli mengalami perubahan menjadi metode tafsir "hermeunetic politis" yaitu yang dihubungkan dengan sejarah politik reformasi khususnya di Zurich. Setelah peristiwa "perdebatan Zurich" yang menghasilkan kemenangan Zwingli dengan dukungan dewan kota, maka dewan kota menjadi suatu lembaga yang berhak menafsirkan Alkitab bagi gereja dan masyarakat Zurich. Dewan kota secara sepihak melepaskan diri dari pengaruh Paus dan, menyatakan bahwa mereka kini sebagai pengganti paus, dan secara otomatis berhak mengurusi masalah-masalah teologis dan keagamaan, termasuk menafsirkan Alkitab bagi warga Zurich. Hal ini jelas dikarenakan prinsip yang dimiliki Zwingli bahwa kota dan gereja Zurich merupakan kesatuan dan merupakan lemabaga/ atau badan yang sama.

Pada bulan Oktober 1523 setelah diadakan perdebatan yang kedua, dewan kota memerintahkan untuk mengeluarkan salib, mezbah, patung dan orgel dari gereja, serta misa dihentikan dan kebaktian dibuat sederhana. Bagi Zwingli ajaran sesat gereja Katholik Roma tidak mungkin hilang apabila bentuk gereja tidak diubah, dan tanda-tanda yang menyertainya.

\footnotetext{
12 Ibid., 191-194.

${ }^{13}$ Ibid., 142-143.
}

Copyright (C) 2021; Ritornera - Jurnal Teologi Pentakosta Indonesia, ISSN 2797-7676 (online), 2797$717 \times$ (print) $\mid 51$ 
Teologia Zwingli tentang Sakramen Perjamuan Tuhan sebagai "ketidak-hadiran Kristus yang nyata".

Teologia Zwingli mengenai Sakramen Perjamuan Tuhan dikenal dengan sebutan "ketidak-hadiran Kristus yang nyata", yang kontras dengan pemahaman/konsep umum pada waktu itu yaitu "kehadiran yang nyata" atau "transubstansiasi". Pemikiran Zwingli pertama kali dipengaruhi oleh Cornelius Hoen yang mengkritik secara radikal ajaran transubstansiasi. Hoen mempermasalahkan pengertian kata est (bahasa latin) dalam frase hoc est corpusmeum, yang menurutnya tidak boleh diterjemahkan secara harfiah menjadi "adalah", karena terjemahan yang benar adalah significant yang berarti "menandakan". Hoen menambahkan argumentasinya dengan mengambil contoh lain, bahwa perkataan Kristus dalam Yoh. 6:48: “Akulah Roti Hidup”, bukanlah berarti Yesus mengidentifikasikan dirinya sebagai sepotong roti atau roti secara umum. Jelaslah bahwa kata "adalah" tersebut harus dipahami secara metaforis atau nirharfiah. Zwingli menyetujui pandangan Hoen tersebut dengan menyatakan bahwa kata-kata Kristus dalam Mat. 26 "inilah tubuhKu" harus dipahami sebagai metaforis atau figuratif, karena pengertian tubuh adalah tubuh Kristus yang telah dikorbankan di kayu salib. Roti tidak mungkin berarti tubuh, jadi jelas kata “adalah" jangan dipahami sebagai arti harafiah.

Sakramen menurut Zwingli adalah tanda dari sesuatu yang suci, roti adalah simbol dari tubuh Kristus yang telah dikorbankan untuk menebus dosa kita. Sedangkan tubuh Kristus yang nyata sekarang duduk di sebelah kanan Allah. Menurutnya kita harus membedakan hal yang ditandakan dan tanda itu sendiri, yang sebenarnya merupakan dua hal yang berbeda sehingga tidak mungkin roti adalah tubuh. Hal ini jelas bertentangan dengan pendapat Marthin Luther karena dalam hal ini ia masih menganut paham bahwa Kristus hadir dalam ekaristi, dimana barang siapa menerima roti dan anggur maka ia menerima Kristus. Luther justru berpendapat bahwa kehadiran Kristus berada di sebelah kanan Allah jangan diartikan secara harfiah, karena kehadiran Kristus dapat dimana saja dan tidak terbatas oleh tempat, mungkin saja "tempat di sebelah kanan Allah" itu berarti "lingkungan pengaruh Allah" atau "kekuasaan Allah".

Bagi penganut paham transsubstansiasi memakan roti berarti memakan tubuh Kristus sendiri. Zwingli lebih menekankan arti spiritual dari memakan tubuh Kristus yaitu percaya dengan hati dan jiwa dalam kemurahan dan kebaikan Allah melalui Kristus, hal itu juga mengandung pengertian kepastian iman yang tidak tergoyahkan bahwa Allah akan menganugerahkan pengampunan dosa dan sukacita keselamatan abadi oleh karena anakNya 
yangmemberi tubuhNya bagi kita. Itulah maksud kita memakan tubuh Kristus saat sakramen berlangsung.

Zwingli menyimpulkan ide tentang Perjamuan Tuhan sebagai jaminan, yang diilustrasikannya dengan sebuah cincin pernikahan. Seperti sebuah cincin yang diberikan oleh mempelai laki-laki kepada mempelai perempuan, cincin itu adalah sebuah benda yang merupakan gambaran jaminan kesetiaan mempelai pria pada mempelai wanita. Mempelai wanita ketika menerima ketika menerima cincin tersebut percaya dan yakin bahwa mempelai laki-laki itu adalah miliknya dan ia sebagai mempelai wanita mengalihkan hatinya dari semua laki-laki yang pernah mencintainya, kepada satu laki-laki saja yaitu suaminya itu, dan hatinya melekat pada suaminya serta tujuan hidupnya hanyalah untuk menyenangkan suaminya. Ide yang cemerlang ini berhasil menggambarkan bahwa Kristus tidak perlu hadir dalam roti dan anggur, karena roti dan anggur sudah menjadi jaminan.

Untuk menentang teologia "transubtansiasi” dan "consubtansiasi”, Zwingli juga menyusun sebuah pandangan lain yaitu prinsip analogi atau asosiasi. Kembali lagi ia mengambil contoh cincin untuk menjelaskan teologinya tentang Perjamuan Tuhan. Cincin adalah seebuauh benda yang terbuat dari emas, namun apabila cincin itu diletakkan dalam dua konteks yang berbeda maka asosiasi kita akan berlainan. Sebuah cincin apabila diletakkan di atas meja, maka ia tak lain adalah sebuah cincin biasa yang sama denga perhiasan lainnya. Namun ketika cincin kita tempatkan dalam konteks yang berbeda maka asosiasinya akan berubah. Misalnya cincin itu dilekatkan di jari seorang ratu, sebagai sebuah hadiah dari raja. Cincin itu jelas berhubungan dengan otoritas, keagungan dan kekuasaan raja. Nilai dari cincin ini sekarang jauh lebih besar daripada sebuah logam saja. Asosiasi kita muncul karena ada peralihan dari konteks yang semula ke konteks yang baru, namun perlu diingat cincin itu sendiri tidak pernah berubah.

Demikian juga dengan roti perjamuan, tidak berubah wujud dirinya, tetapi pengertiannya berubah secara kontras/dramatis. Jadi pengertian kita itu atau asosiasi kita terhadap objek dapat berubah tanpa ada perubahan apapun dalam hakikat objek tersebut. Zwingli menambahkan bahwa roti dan anggur dalam konteks sehari-hari merupakan roti dan anggur biasa, tanpa adanya asosiasi khusus. Tetapi ketika ditempatkan di tengah-tengah ibadah Perjamuan Tuhan untu memperingati pengorbanan Kristus, maka roti dan anggur itu menjadi suatu peringatan yang dahsyat akan peristiwa yang mendasar dalam iman Kristen. 
Konteks itulah yang memberikan makna berbeda, tetapi anggur dan roti tidak berubah didalam dirinya atau zatnya. ${ }^{14}$

\section{Teologia Zwingli mengenai Sakramen Baptisan (Anak)}

Pada mulanya Zwingli belum dapat merumuskan dengan pasti posisinya mengenai Baptisan Anak. Di satu sisi ia setuju pendapat Agustinus, Bapa Gereja abad ke-5 yang mengemukakan tentang dosa asal. Upacara pembaptisan dapat menyucikan dosa asal, itu adalah pandangan tradisional. Zwingli belum mengambil sikap, karena di sisi lain ia masih terpengaruh oleh pendapat Erasmus bahwa dosa asal itu tidak ada, sehingga baptisan anak tidak mempunyai makna.

Setelah sekian lama mengalami kesulitan dalam merumuskan teologinya tentang baptisan anak, akhirnya Zwingli mengemukakan teologinya dengan mengambil pijakan dari konsep sunat di PL, bagi orang Israel bayi laki-laki disunat beberapa hari setelah dilahirkan sebagai tanda keanggotaan mereka dalam umat Israel. Sunat dalam PL dipandang sebagai upacara yang ditetapkan sebagai demonstrasi terhisabnya anak itu ke dalam persekutuan perjanjian, sekaligus anak itu masuk dalam komunitasnya. Zwingli berpendapat bahwa baptisan adalah suatu padanan yang lembih lembut dari sunat, karena baptisan tidak merasakan sakit atau pertumpahan darah, lebih bersifat inklusif karena dapat melibatkan bayi laki-laki dan perempuan. Baptisan merupakan suatu tanda keterhisaban ke dalam komunitas gereja. Zwingli menganut paham "negara" dan "gereja" merupakan dua hal yang sebenarnya sama, dengan demikian "sebuah kota Kristen sama dengan sebuah gereja Kristen”. Dengan demikian sakramen-sakramen menandakan kesetiaan tidak hanya untuk gereja saja, melainkan juga untuk masyarakat kota. Di kot Zurich ini Zwingli menerapkan prinsip ini, sehingga apabila ada seseorang atau sekelompok orang yang menolak Baptisan Anak berarti ia telah menunjukkan tindakan yang tidak setia kepada masyarakat kota Zurich. Hakim berwewenang untuk mengusir dari Zurich orang yang menolak baptisan anak. Prinsipnya akhirnya membuat sebuah kontroversi dengan golongan Anabaptis yang menolak baptisan anak dan menginginkan keterpisahan antara gereja dan negara.

\section{Pertentangan Zwingli dengan Kelompok Anabaptis}

Pada mulanya Zwingli, Condard Grebel dan Felix Manz bersama-sama mempertahankan koalisinya untuk sama-sama mempertahankan Reformasi Magisterial. Tetapi akhirnya mereka berselisih pendapat karena Zwingli mempertahankan prinsip Baptisan Anak sedangkan Grebel dan Manz menolak baptisan anak. Lalu pada tanggal 15

\footnotetext{
${ }^{14}$ Ibid, hal. 228-229.
}

Copyright(C2021; Ritornera - Jurnal Teologi Pentakosta Indonesia, ISSN 2797-7676 (online), 2797$717 \mathrm{x}$ (print) $\mid 54$ 
Januari 1525 diadakan perdebatan umum mengenai pembaptisan yang benar menurut Alkitab. Melalui perdebatan tidak dijumpai kata sepakat, akhirnya kelompok Grebel memisahkan diri dari Gereja-Kota Zurich karena dewan kota lebih setuju untuk mempertahankan baptisan anak. Dengan demikian kelompok separatis ini akan menghadapi bahaya hukuman dari dewan kota. Rupanya ancaman itu justru membuat mereka lebih berani menyatakan imannya, dan beberapa hari setelah perdebatan yaitu pada tanggal 21 Januari 1525 di rumah Felix Manz diadakan pembaptisan orang dewasa pertama kali yang dilakukan oleh Grebel terhadap George Blaurock mantan imam dari Chur, setelah itu terjadi lagi pembaptisan beberapa orang lainnya. Setelah mereka berhasil mengembangkan ajarannya di beberapa tempat di Swiss, pihak dewan kota akhirnya memenjarakan tiga pemimpin kunci gerakan anabaptis ini yaitu Grebel, Manz dan Blaurock pada tanggal 18 November 1525, dengan alasan tidak setia kepada masyarakat Zurich. Grebel sendiri akhirnya mati karena suatu penyakit di sel penjara. Pada 7 Maret 1526 pihak otoritas kota Zurich mengeluarkan mandat bahwa praktek pembaptisan ulang akan mengakibatkan hukuman mati. Tragisnya Felix Manz menjadi martir pertama yang dihukum mati oleh pihak dewan kota Zurich yang notabene dipengaruhi oleh teologia Zwingli. Felix Manz mati dianiaya oleh pihak dewan kota Zurich, ia digiring dari penjara Wellenberg Zurich ke dermaga perahu. Manz tetap memuji Tuhan tatkala ia diseret ke tempat eksekusi, ia tidak takut mati, malahan ia merasa itu karunia karena bahwa ia mati untuk membela kebenaran. Ketika digiring menuju dermaga, ibunya dan adiknya mendukungnya untuk mempertahankan imannya, kaki dan tangan Manz diiikat, sesaat sebelum ia didorong ke dalam air yang dalam, manz menyanyi dengan suara nyaring In Mannus tuas, Domine, commendo spiritum meum. "ke dalam tanganMu Tuhan aku serahkan rohku". Manz didorong ke dalam air dan ditenggelamkan sampai mati. Sungguh tragis pemerintahan yang terbentuk oleh sebuah reformasi telah berbuat tindkan yang keji sehingga mencabut nyawa seseorang.

\section{Perbedaan antara Zwingli dan Martin Luther}

Pada bulan Oktober 1529 di Marburg terjadi perdebatan umum antara Zwingli dan Luther mengenai Perjamuan Tuhan perbedaan antara Zwingli dan Luther dipicu oleh pengertian yang berbeda dalam menafsirkan kata-kata dalam Mat. 26:26 hoc est corpus meum. Bagi Luther est berarti “adalah”, bagi Zwingli kata itu berarti "menandakan”.

Keduanya memang menolak prinsip Transubstansiasi yang dianut oleh Gereja Katolik Roma. Perlu dijelaskan terlebih dahulu prinsip transubstansiasi ini, pada awalnya 
prinsip ini berakar dari filsafat Aristoteles yang menyatakan terdapat dua hal yang menjadi satu yaitu Form and Matter atau bentuk dan materi, yang merupakan suatu materi dan bentuk tidak dapat dipisahkan. Berbeda dengan Filsafat Plato yang menyatakan suatu benda atau materi berada di bumi, sedangkan bentuk dan ide berada di atas. Jadi, 'ide' dalam filsafat Plato tidak mungkin ditemukan didunia ini, karena di dunia ini kita hanya melihat bayangbayang saja. 'Ide' lebih tinggi dari kenyataan, 'ide' lebih tinggi dari benda, sehingga bentuk dan benda itu terpisah. Kemudian Aristoteles menolak pandangan gurunya itu, ia menyatakan 'ide' bukan berada diatas tetapi berada bersama bentuk dan bentuk bersama dengan bendanya. Pengaruh Aristoteles meresap ke dalam pandangan sakramen, karena bentuk dan benda tidak dapat dipisahkan, maka aplikasinya tubuh Kristus dan Roti juga tidak dapat dipisahkan inilah yang dinamakan transubtansiasi.

Luther menolak pandangan ini, dan menganut pandangan Consubtansiasi yang artinya pada saat kita mengadakan Perjamuan Tuhan maka Kristus sungguh-sungguh menyertai roti dan Anggur. Darah dan tubuh Kristus tidak menjadi satu dengan roti dan anggur melainkan Kristus yang pernah mati dan bangkit bagi kita hadir dan menyertai roti dan anggur. ${ }^{15}$

Zwingli menolak transubtansiasi dan consubtansiasi, baginya roti dan anggur adalah lambang, dan Kristus diperingati dalam ketidakhadiranNya, termasuk Kristus tidak menyertai juga dalam Perjamuan Tuhan.

Perdebatan ini akhirnya berimbas keterpisahan. Perserikatan milter dan politis yang tadinya mereka rencanakan untuk memperkokoh reformasi di Eropa. Sebaliknya yang terjadi adalah perpecahan sampai-sampai Luther dengan emosi setelah perdebatan itu berkata: "Engkau berasal dari roh yang lain dari pada kami". ${ }^{16}$

Perselisihan pendapat antara keduanya terjadi pula dalam hal keberadaan Kristus yang sekarang duduk di sebelah kanan Allah, bagi Zwingli ini berarti Kristus tidak hadir dimanapun. Luther menolak pandangan Zwingli dengan menyebutnya sesuatu yang naif tanpa dasar filosofis dan tidak dapat dipertanggungjawabkan. Kehadiran Kristus tidak dapat dibatasi dengan ruang dan waktu, Kristus hadir dimana-mana. ${ }^{17}$

\section{Penghargaan dan Kritik Terhadap Teologi dan Cara Reformasi dari Zwingli}

Penghargaan terhadap Zwingli

15 Tong, Stephen., Reformasi dan Teologi Reformed. Jakarta : LRII, 1994.

${ }^{16}$ Berkhof H., dan Enklaar, I., Sejarah Gereja. Jakarta : BPK Gunung Mulia, 2001.

${ }^{17}$ McGrath, A., ibid , 233. 
Zwingli adalah pejuang reformasi yang gigih, sejak usia muda yaitu 22 tahun, ia mulai melakukan tindakan yang kontra dengan keadaan disekitarnya waktu itu. Rasa nasionalisme yang tebal nampak ketika ia memprotes keberadaan tentara bayaran Swiss untuk membela kepentingan negara lain dan untuk kepentingan Paus. Tindakannya yang menentang penjualan surat Indulgensia dana menentang kekuasaan paus patut dipuji. Kesukaannya untuk melakukan perdebatan di muka publik menunjukkan sikapnya yang pemberani dan terus terang. Dampak perdebatan-perdebatan ini bagi dirinya sangat positif, karena pendapatnya dengan cepat mempengaruhi komunitasnya di kota Zurich khususnya. Perdebatannya dengan pihak katolik Roma untuk mempertanggungjawabkan tindakannya ketika menghapus larangan makan daging saat puasa, dan petisi yang memerintahkan para imam untuk menikah yang dirangkum dalam 67 dalil, ternyata berpengaruh besar pada komunitasnya. Mungkin tanpa ia duga sebelumnya, pihak otoritas Zurich justru mendukung tindakannya.

Sejak dewan kota mendukung tindakan Zwingli, maka dengan leluasa ia melakukan reformasi di seluruh kota Zurich, dan mencita-citakan di seluruh negeri Swiss. Teologianya yang menganggap kota dan gereja adalah badan yang harus sama mulanya didasari atas kerinduannya yang agung yaitu ingin menjadikan komunitas di Zurich menjadi komunitas yang bermoral yang berdasarkan Alkitab. Ia merindukan adanya kota Kristen yang masyarakatnya menjunjung tinggi nilai moral. Zwingli yakin apabila Gereja dan Kota dijadikan satu maka proses pembaruan moral di Zurich akan berlangsung lebih cepat. Sehingga praktis dalam beberapa tahun saja reformasi di Zurich dapat tercapai.

Di dalam 67 dalil/thesis yang dikemukakan oleh Zwingli, nampaklah keagungan teologianya. Didalamnya nyata hakikat Injil yang sebenarnya, baginya inti Injil adalah Kristus. Ia ingin mengembalikan Alkitab pada posisi yang sebenarnya, selama waktu itu Alkitab dikendalikan oleh paus, dan paus hanya memanipulasi Alkitab untuk kepentingannya sendiri. bagi Zwingli, Alkitab lebih berkuasa daripada paus. Zwingli menekankan bahwa hanya kristuslah yang layak disembah, dan Maria, Paus serta para Santo tidak layak disembah. Keselamatan dikarenakan kita percaya pada Injil, bukan karena perbuatan kita ataupun karena tradisi. Pernikahan untuk para imam/rohaniwan tidak dilarang oleh Alkitab, hal ini ditekankan oleh Zwingli mengikat banyak praktek perzinahan justru karena adanya tekanan yang melarang para imam untuk menikah. Hierarkinya yang berlaku di gereja Katolik Roma menurutnya tidak ada dasar Alkitabiahnya, bagi orang Kristen hanya Kristuslah Kepala Gereja bukan paus, dan Kristus juga yang teratas dari segalanya. Prinsip pengampunan dosa yang dilakukan oleh katolik pun ia tolak karena yang 
benar pengampunan dosa itu langsung dari Tuhan tanpa perantaraan manusia/imam Katholik. Ia juga menolak prinsip Purgatori. Ke-67 dalil merupakan tindakan revolusioner yang sangat berani untuk menembus tirani kekuasaan paus yang sudah sangat menyimpang.

Tindakan Zwingli untuk merobohkan patung-patung di gereja, patut juga dihargai karena ia ingin mengembalikan Kekristenan pada imannya yang sejati, baginya penghormatan kepada patung-patung tersebut termasuk kategori penyembahan berhala. Misa yang berlangsung dengan tata cara yang kaku, dan terkesan rumit diubah menjadi bahasa setempat yang dimengerti oleh umat. Khotbah-khotbah yang telah diatur sesuai pesanan Paus ditolaknya, ia mengganti tema khotbahnya dengan mengeksposisi langsung Alkitab sehingga khotbanynya selalu segar dan membuat jemaat lebih bergairah.

Pandangannya tentang Perjamuan Tuhan telah berhasil menempatkan pengertian Perjamuan Tuhan pada tempat yang sebenarnya, ia berhasil menafsirkan Perjamuan Tuhan sebagai tanda peringatan akan karya Kristus dan sebagai tanda persekutuan antara umat yang percaya pada Kristus. Zwingli berhail melepaskan belenggu praktek Perjamuan Tuhan yang salah, yang dilakukan orang Kristen selama berabad-abad. Sekaligus ia membuka mata rohani orang Kristen tentang pengertian yang benar akan Perjamuan Tuhan.

Masyarakat Zurich menjadi tertarik pada figur Zwingli karena aktivitasnya yang berintegritas berlainan dengan para rohaniwan lainnya pada waktu itu. Ia berhasil menciptakan suatu komunitas Kristen di kota Zurich yang menjadi contoh bagi kota-kota lainnya di Swiss dan Eropa. Berkat dukungan dewan kota, maka reformasi di Zurich dapat tercapai, kota Basel, kota Bern mengikuti pola reformasi Zwingli, yang puncaknya pola ini berpengaruh pada kota Jenewa yang berhasil meneruskan cita-cita Zwingli oleh penerusnya, yang menjadi lebih terkenal darinya yaitu Yohanes Calvin.

\section{Kritik terhadap Pemikiran Zwingli}

Walaupun diakuai bahwa prestasi Zwingli mereformasi kota Zurich dan dampaknya ke seluruh Eropa patut mendapat apresiasi tinggi, namun banyak juga kelemahan-kelmahan teologia Zwingli yang patut dikritisi. Sifatnya yang keras dan pemberani adalah kelebihannya dan sekaligus kekurangannya juga. Dengan keberaniannya ia berani berdebat di depan publik, namun partner debatnya akhirnya dapat menjadi lawannya. Bahkan dalam kasus Anabaptis, teman partnernya itu harus menjalani hukuman mati dan menjadi martir. Sikap keberaniannya itu juga yang membawanya rela menjadi pejuang fisik, dan terjun dalam medan peperangan fisik melawan pihak Katolik, yang akhirnya membuat ajal Zwingli terenggut disana. Sikapnya yang keras dan non-kompromis jsutru menjadi bumerang 
baginya, ketika ia harus bertentangan dengan teman-temannya sesama reformator mengenai pembaptisan anak.

Hal ini sebenarnya dipicu dari pandangannya tentang gereja dan kota Zurich adalah badan yang hakikatnya satu. Prinsipnya ini menjadi perlu dikaji ulang, karena menimbulkan banyak kerugian pada reformasi Zwingli sendiri. Dengan mempertahankan bahwa Gereja dan kota harus satu, maka baptisan anak yang menjadi tanda masuknya seseorang ke dalam persekutuan gereja berarti ekaligus menjadi tanda masuknya seseorang dalam komunitas kota Zurich. Hal ini menjadi Kontroversi bagi Zwingli ketika menghadapi kenyataan terdapat kelompok orang yang menolak baptisan anak dianggap sebagai pembangkang terhadap pemerintahan kota Zurich. Walaupun tidak ada bukti bahwa Zwingli terlibat langsung dalam penghukuman mati terhadap Felix Manz tokoh Anabaptis, namun terbukti bahwa penolakan Zwingli terhadap Anabaptis yang diperlihatkannya melalui perdebatan di depan publik, telah memancing dewan kota untuk bertindak keras terhadap kelompok Anabaptis. Perlu dikritik dengan keras bahwa tindakan Zwingli yang berpengaruh pada dewan kota sehingga berbuat kejam dengan menghukum mati saudaranya seiman yang beda pendapat. Ini sungguh ironis, apalagi Zwingli pernah menulis kata-kata mutiara yang mengutamakan kasih di atas segalanya, kata-kata tersebut sebagai berikut :

Di dalam inti sari, kesatuan.

Di dalam hal yang bukan intisari, kebebasan.

Di dalam segala sesuatu, kasih. ${ }^{18}$

Seharusnya Zwingli berusaha mempengaruhi dewan kota agar bertindak dengan kasih, sehingga tidak perlu ada hukuman mati apalagi terhadap teman seiman. Kasih hanya menjadi slogan ketika nyawa seseorang dicabut dengan semena-mena, apalagi karena tindakan yang dilakukan oleh si terdakwa bukan tindakan kriminal, melainkan praktek agama yang ia yakini, namun bukan yang diyakini oleh mayoritas komunitas di Zurich. Nampak disini ketidak-kosnsitenan Zwingli dalam bertindak sesuai prinsip kasih yang ia yakini.

Kelemahan prinsip penyatuan agama dengan negara seperti yang dianut oleh Zwingli juga beresiko siap membela negara untuk melawan musuh negara, walaupun perlawanan yang dilakukan melalui peperangan secara fisik, yang secara otomatis membunuh sesama manusia adalah perbuatan yang sah, bahkan suatu tindakan patriotisme. Hal ini tentunya jauh dari prinsip kasih yang memerintahkan kita untuk mengasihi musuh kita sekali pun.

\footnotetext{
${ }^{18}$ Ira., Ibid., hlm. 123.
}

Copyright (C) 2021; Ritornera - Jurnal Teologi Pentakosta Indonesia, ISSN 2797-7676 (online), 2797$717 \mathrm{x}$ (print) $\mid 59$ 
Hal ini dikarenakan prinsip membela negara sama dengan membela gereja sama dengan juga membela Tuhan. Zwingli akhirnya dapat terjebak kedalam praktek yang pernah Paus lakukan, yang mana demi kepentingan Paus atau gereja, negara diperalat. Umat menjadi bingung apakah perjuangan yang mereka lakukan untuk kepentingan gereja (tuhan) atau untuk kepentingan negara (dalam hal ini dewan kota Zurich). Seharusnya dari awal Zwingli harus menyadari konsekuensi teologinya yang menyatukan agama dan negara yang dapat diselewengkan oleh pihak-pihak tertentu yang ingin mendapat keuntungan secara pribadi/golongan semata.

Kritik terhadap Zwingli perlu diajukan juga terutama tentang baptisan anak yang ia yakini, bahwa Baptisan Anak merupakan tanda seseorang masuk ke dalam persekutuan gereja sekaligus masuk ke dalam komunitas kota Zurich. Berarti apabila seseorang anak tidak mengalami pembaptisan maka ia bukan hanya tidak termasuk anggota gereja, namun juga ia tidak termasuk sebagai warga kota Zurich, dan haknya sebagai warga kota tidak ia punyai. Tentunya ketika ia dewasa akan mempunyai masalah dalam lingkungan masyarakat kota Zurich, dan bisa saja ia menjadi terkucilkan atau termarginal. Seharusnya upacara pembatisan tidak menimbulkan adanya umat yang terpinggirkan dari komunitas mayoritas, Alkitab tidak mengajarkan bahwa pembaptisan menjadikan umat terpecah atau terbagi. Nampaknya praktek pembaptisan ini telah jauh dari pengertian yang benar di dalam Alkitab, apalagi ditambah dengan timbulnya hukuman mati bagi orang yang menolak baptisan anak.

Sebenarnya prinsip yang diajukan oleh kaum Anabaptis mengenai penolakan baptisan anak harus kita pertimbangkan pula, karena tidak mungkin seorang anak akan mengerti atau paham arti pembaptisannya mengingat daya pikir mereka belum matang. Serta tidak mungkin iman orang tua menyelamatkan anak-anaknya, karena keselamatan bersifat personal/invidu bukan bersikap kolektif. Pembaptisan yang dilakukan saat orang itu sudah paham pengertian pembaptisan tersebut, justru lebih bernilai daripada baptis anak. Hanya waktu itu pemahaman kelomppok Anabaptis dianggap menentang arus utama, sehingga mereka harus mengalami penganiayaan, dan banyak yang menjadi martir.

Korelasi dari penolakan Baptisan Anak ini pastilah tertuju pada konsep agama dan negara. Kelompok Anabaptis menolak penyatuan negara dan gereja, mereka telah melihat dampaknya, demi membela kepentingan gereja, negara menunjukkan arogansinya (bahkan mengatas-namakan Tuhan) dengan membuat aturan yang menghukum pembangkang gereja. Disini nampak bahwa prinsip penyatuan gereja dan negara beresiko tinggi untuk disalah gunakan dan patut ditolak. 
Kritik terhadap Zwingli yang perlu dikemukakan lagi adalah prinsip penafsiran Alkitab yang dianut Zwingli. Ia lebih mengakui prinsip "hermeneutik politis" yang berarti hak penafsiran Alkitab ditentukan oleh dewan kota Zurich. Ini jelas menjadikan penafsiranpenafsiran yang dilakukan di luar dewan kota dianggap tidak sah. Berarti Zwingli telah memandulkan potensi individu untuk menafsirkan Alkitab, padahal pada permulaan reformasinya Zwingli lebih berpihak pada prinsip tafsir individual, seiring dengan berjalannya waktu ia menjadi kompromi dengan dewan kota untuk memakai tafsir "hermeneutik politis". Sekali lagi prinsip penafsiran ini bisa menyimpang jauh dari arti Alkitab sebenarnya, karena kepentingan-kepentingan dewan kota akan lebih dikemukakan dari pada kepentingan Tuhan yang murni. Juga akan menutup adanya keterbukaan perbedaan tafsiran dengan individu atau sebuah golongan di masyarakat Zurich. Suara dari bawah menjadi tersumbat, dan bisa saja dewan kota bertindak represif dalam penafsirannya.

\section{Aplikasi Reformasi Zwingli untuk Pelayanan Masa Kini}

Pada masa kini jiwa reformasi Zwingli masih perlu dikobarkan, karena beberapa gereja yang dulunya hasil reformasi mulai menjadi gereja degadrasi iman, dan kehidupan bergerejanya mulai menyimpang dari ajaran Firman Tuhan. Banyak para rohaniwan saat ini melakukan tindakan yang jauh dari teladan Kristus.

Di Indonesia banyak terdapat gereja dengan beratus-ratus denominasi, namun hanya sedikit gereja yang sudah menyatakan teladan dan kesaksian yang nyata bagi sesamanya. Banyak gereja saat ini hanya berfokus pada pembangunan gedung gereja saja, tanpa memperhatikan lebih intensif terhadap pembangunan moral atau iman umat.

Pengaruh informasi dan teknologi serta nilai-nilai yang beda bahkan bertentangan dengan nilai-nilai Alkitab sangatlah besar dampak yang ditimbulkannya. ${ }^{2}$ Bertambah majunya teknologi dalam milenium ketiga ini tidak serta merta membawa kemajuan dalam moral manusia. Malahan sebaliknya, teknologi yang maju telah membuat manusia semakin menjadi liar dan makin sulit mengendalikan dirinya. Teknologi informasi telah digunakan manusia untuk memuaskan hawa nafsunya, internet telah menjadi ajang pemuasan hasrat sex manusia yang menyimpang, situs pornografi menjadi situs paling menguntungkan di internet. Di lingkungan gereja kemajuan teknologi telah membawa berkat bagi perluasan Injil, namun kadang kala dapat menjadi kendala, karena kemajuan teknologi telah membentuk suatu budaya baru, yaitu budaya Hedonisme. Hedonisme dipopulerkan oleh

\footnotetext{
${ }^{2}$ Angin, Y.P.H., \& Yeniretnowati., Peran Kepala Keluarga Kristen (Ayah) dalam mendidik Anak
} Generasi Z dan Alpha. Apostolos : Journal of Theology and Christian Education, 1(1), 1-12, 2021. 
kemajuan teknologi media massa seperti lewat TV, Radio, dan media cetak. Bagi Hedonism yang terpenting adalah kesenangan materi. Di lingkungan gereja paham Hedonisme pun telah banyak dianut secara sadar maupun tidak sadar. Teologia Kesuksesan yang pernah populer telah menjerumuskan umat kepada pola hidup materialisme atau hedonisme.

Era digital yang dihadapi saat ini tidaklah mudah. Kemajuan teknologi dan informasi yang canggih dan sangat cepat ini memerlukan perubahan perspektif dari para orangtua dan para pemimpin Kristen dalam menjalankan tugas dan panggilan pengabdiannya agar tetap dapat adaptif dalam menjalani perubahan yang ada di era digital ini namun tetap dapat berpegang teguh pada prinsip-prinsip pendidikan Kristen. ${ }^{3}$

Banyak pertemuan-pertemuan ibadah atau kebaktian didakan di hotel-hotel berbintang di kota-kota besar, ruangan yang nyaman dan mewah, fasilitas yang lux, namun belum tentu membawa gereja pada visi dan misinya yang benar. Bahkan kecenderungan memperkaya Gereja lebih dominan dari pada memperhatikan rakyat miskin yang memerlukan bantuan kita. lebih kurang ada kemiripan dengan era yang dulu pernah terjadi di Swiss saat Zwingli mempersoalkan kehidupan gereja yang akhirnya dengan berani beliau mengkritisinya. ${ }^{4}$

Tak luput juga dari perhatian yaitu istilah "Hamba Tuhan bayaran", hamba Tuhan seperti ini (sekalipun tidak semua demikian) hanya mau melayani di kota-kota besar, menginapnya harus di hotel berbintang, transportasinya wajib pesawat terbang dan lain-lain. Maka tidak sedikit saat ini banyak kalangan menyoroti gaya hidup pelayan Tuhan, mungkin mereka menilai bahwa berkat datang dari Tuhan melalui perolehan yang besar datang bertubi-tubi untuknya. Semakin rohani mereka maka mereka yakin itu akan berakibat semakin banyak berkat Allah, dan pasti semakin kaya juga mereka. Mereka memandang berkat Allah sebagai berkat materi semata-mata

Dalam keadaan seperti itulah perlu adanya orang yang berani merombak, memprotes, mengingatkan gereja untuk kembali kepada jalur rencana Allah, orang yang mempunyai semangat seperti Zwingli untuk terbuka mengadakan serangkaian kecaman untuk kebaikan gereja sendiri. Zwingli sendiri dalam melakukan serangkaian tindakan reformasinya bukan tidak mempunyai resiko, ia malah berani mempertaruhkan kedudukannya sebagai Imam di sebuah gereja yang cukup besar di Zurich, sebuah sumber mengatakan bahwa Zwingli telah memperoleh fasilitas yang baik pada saat itu, yaitu sebuah rumah, kuda untuk alat

${ }^{3}$ Yeniretnowati, T.A., \& Angin, Y.P.H., Peran Parenting Orangtua Dalam Perspektif Pendidikan Kristen di Era Digital. Harati : Jurnal Pendidikan Kristen, 1(1), 34-35, 2021. 1993.

${ }^{4}$ Abineno, Dr. J.L., Ulrich Zwingli Hidup, Pekerjaan dan Ajarannya., Jakarta : BPK GM, 15-16, 
transportasi dan gaji sebesar 70 gulden. ${ }^{5}$ Zwingli rela kehilangan jabatan, dan fasilitas yang nyaman demi mempersembahkan ideologinya yang berdasarkan Firman Tuhan, dan demi kecintaannya pada Gereja dan masyarakat agar mempunyai tingkat moral yang tinggi.

Di lingkup gereja, gembala sebagai pemimpin dalam memimpin gereja secara organisatoris dan sekaligus sebagai organisme, orang-orang yang ada di lini kepemimpinan berkembang pemahamannya ataukah tidak tentunya terletak pada cara pandangnya terhadap manusia. Tuhan Yesus Sang Pemimpin Agung kita sudah memberikan keteladanan yang luar biasa dimana Ia yang adalah Tuhan dan Juru Selamat umat manusia rela untuk mengorbankan nyawanya, memberi hidup-Nya dan membasuh kaki pengikut-Nya inilah kepemimpinan yang sempurna, syukur bahwa manusia memiliki profil Pemimpin yang menjadi panutan, contoh, model yang memandang manusia adalah serupa dan segambar dengan Dia, Sang Pencipta. ${ }^{6}$

Di Indonesia sendiri, gereja disebut sebagai "the silent prophet" atau nabi yang bisu, karena ia tidak berani menyuarakan suara yang murni dari Tuhan (baca: Alkitab), meskipun itu harus menentang arus dan siap menghadapi tantangan atau bahkan penganiayaan.

Gereja memerlukan orang seperti Zwingli yang rela keluar dari sarang kenyamanan untuk turun memerangi kebejatan moral bangsanya dan membuka mata rohani umat untuk mengerti pengajaran Firman yang murni.

Pada saat ini juga diperlukan orang seperti Zwingli yang berani merumuskan tatanan pikirannya dalam dalil-dalil atau tulisan-tulisan, dan bersedia melakukan perdebatan di depan publik untuk menyatakan kebenaran Firman. ${ }^{7}$

Perlu juga diaplikasikan cara pendekatan Zwingli dalam melakukan reformasinya dengan melibatkan unsur politik dan pemerintahan. Tidak dapat dipungkiri bahwa unsur penyatuan gereja dan negara akan membawa masalah dalam pelayanan Zwingli selanjutnya, namun bukan berarti kita menghilangkan seluruhnya prinsip ini. Buktinya pada masa kini saat Gereja terpisah dari Negara, banyak gereja yang akhirnya terlena sibuk mengurus kepentingan gerejanya tanpa mau terlibat mengurusi kepentingan negara. Keterpisahan gereja dan negara bukan berarti sama sekali acuh tak acuh terhadap perkembangan negara, gereja perlu pula merangkul orang-orang pemerintahan dengan cara membekali orang-orang percaya yang berkompeten untuk diarahkan terjun dalam bidang politik.

${ }^{5}$ Estep., Ibid.

${ }^{6}$ Angin, Y.P.H., Yeniretnowati, T.A., \& Arifianto, Y.A., Implikasi Nilai Manusia dalam Praksis Kepemimpinan Menurut Kejadian 1:26-27.MAGNUM OPUS : Jurnal Teologi Dan Kepemimpinan Kristen, 2020.

${ }^{7}$ Abineno, Dr. J.L., Ulrich Zwingli Hidup, Pekerjaan dan Ajarannya., Jakarta : BPK GM, 1993. 


\section{KESIMPULAN}

Seharusnya gereja menyadari bahwa terdapat banyak perbedaan tafsiran, dan perbedaan pendapat di lingkungan bergereja, sehingga gereja harus mempunyai sikap yang terbuka untuk menerima pendapat-pendapat itu. Kasus penghukuman mati Anabaptis di Zurich menjadi peringatan sejarah untuk gereja sekarang ini. Tentunya bagi orang yang beriman kepada Kristus, hendaklah menyingkirkan niat untuk bertikai, apalagi hingga terjadinya pembunuhan yang hanya dikarenakan perkara perbedaan pendapat atau perbedaan tafsiran.

Memperjuangkan kebenaran Firman Tuhan memang diperlukan semangat yang penuh, namun janganlah juga menempuh dengan cara anarkis (baca: secara konyol), apalagi dengan sesamanya. Pada dasarnya dari perjuangan fisik yang dilakukan Zwingli dengan memasuki medan pertempuran melawan musuhnya (bersebrangan doktrin), gereja masa kini mendapat banyak pelajaran yang berharga bahwa tindakan perang tidak disetujui Alkitab, seperti membunuh sesama untuk alasan apapun tidak dapat dibenarkan dalam Alkitab. Tindakan anarkis, kekerasan, bahkan peperangan bukanlah cermin dari nilai-nilai kekristenan. Seharusnya memiliki sikap damai, dan menjadi prinsip yang harus dipegang teguh oleh umat Kristen, seperti yang Yesus pernah ajarkan supaya mengasihi musuh.

Mengenai tindakan Zwingli menghapus berhala-berhala di gereja patut diteladani, saat ini tentunya bentuk berhala sudah berlainan, yang jelas berhala adalah sesuatu yang bertujuan untuk menjauhkan umat dari persekutuan dengan Allah. Saat ini "alat elektronik" yaitu Televisi (TV), gadget, dan sejenisnya dapat dimasukkan dalam kategori berhala, apabila benda ini telah mengakibatkan menjauhkan iman umat kepada Tuhan. Berdasarkan pengamatan banyak waktu yang dihabiskan orang untuk menonton TV, pemakaian gadget yang berlebihan dibandingkan merenungkan Alkitab (baca: bible study), oleh karena itu perlu hamba Tuhan supaya mengingatkan umat agar tidak terseret pada "berhala-berhala" tersebut, yang sebenarnya seringkali digunakan iblis untuk menyebarkan ajarannya. Walaupun tidak semua acara yang ditayangkan di TV, atau disajikan oleh media sosial di dalam gadget yang tidak bermanfaat, di sini yang diperlukan adalah hikmat untuk menyeleksi tayangan yang patut ditonton atau membangun mental gereja-gereja masa kini. Jadi sama seperti Zwingli, tugas para hamba Tuhan mengingatkan umatnya agar hati tidak mengarah pada "berhala" tersebut, yang berbeda mungkin bentuk dari berhala modern saat ini, selain TV masih banyak berhala modern yang lain misalnya: uang, pekerjaan, sex, narkoba, mode, teknologi dan lain-lain. Gereja harus dibawa untuk hidup benar secara iman dan menjauhi berhala yang menjauhkan mereka dari hidup sejahtera. 
Perlu diadakan pendidikan dan pengarahan profesional secara iman Kristen kepada generasi muda saat ini, untuk menyiapkan mereka terjun ke dalam berbagai profesi termasuk politik, sehingga suatu saat mereka akan berhasil memberi pengaruh pada komunitasnya, yang akhirnya dapat menegakkan nilai moral Kristiani.

Pembinaan warga gereja seharusnya mengarahkan umat untuk turut serta membangun kehidupan yang bermoral bagi bangsanya, dan mengajak umat yang mempunyai talenta masuk dunia politik agar mau menegakkan prinsip-prinsip Alkitab di dalamnya. Para Hamba Tuhan dalam khotbah-khotbahnya harus berani juga membahas permasalahan di masyarakat, sehingga gereja tidak menjadi "nabi bisu" di dalam menanggapi permasalahan di masyarakat.

Perlu diingat pula, apabila seorang Kristen berhasil diakui oleh pemerintah dan menjadi pejabat di struktur pemerintahan, ia jangan menjadi arogan dan menggunakan kekuatan politiknya untuk menentang bahkan menghukum orang-orang yang tidak sepaham dengannya. Kita harus belajar dari kasus kelompok Anabaptis di Zurich, walaupun secara notabene pemerintahan di Zurich adalah pemerintahan Kristen, namun karena tidak mau terbuka terhadap perbedaan pendapat, akhirnya mereka menempatkan diri sebagai hakim atas saudaranya, dan mencabut nyawa saudaranya dengan cara otoriter.

\section{REFERENSI}

Abineno, Dr. J.L., Ulrich Zwingli HIdup, Pekerjaan dan Ajarannya., Jakarta: BPK GM, 1993

Johanes Calvin., Pembangunan Jemaat, Tata Gereja, dan Jabatan Gerejawi., Jakarta: BPK GM, 1997

Angin, Y. H. P., \& Yeniretnowati, T. A. (2021). Peran Kepala Keluarga Kristen (Ayah) dalam mendidik Anak Generasi Z dan Alpha. Apostolos: Journal of Theology and Christian Education, 1(1), 1-12.

Angin, Y. H. P., Yeniretnowati, T. A., \& Arifianto, Y. A. (2020). Implikasi Nilai Manusia dalam Praksis Kepemimpinan Menurut Kejadian 1: 26-27. MAGNUM OPUS: Jurnal Teologi Dan Kepemimpinan Kristen, 2(1), 47-61.

Berkhof H., dan Enklaar, I., Sejarah Gereja. Jakarta : BPK Gunung Mulia, 2001

Estep, W.R., The Reformation And Protestantisme, Texas: Carib Baptist Publications, 1983 Gonzales, Justo L., The Story of Christianity (Vol. 2)., NY: HarperCollinsPublisher, 1985 Grant, Robert M., Sejarah Singkat Penafsiran Alkitab. Jakarta : BPK Gunung Mulia, 1993 Lane, Tony., Runtut Pijar: Sejarah Pemikiran Kristiani, Jakarta: BPK Gunung Mulia, 1993

McGrath, Alister E., Sejarah Pemikiran Reformasi, Jakarta: BPK Gunung Mulia, 1997 2007 ., Christian Theology: An Introducton., USA: Blackwell Publishing,

Sasongko, Nindyo., Restitusi Kontra Reformasi?: Reformasi Zurich dan Kelahiran Si Anak Tiri., Jurnal Veritas, Volume 5, No.2., Malang: SAAT, 2004 
Schaff, Philip., History of The Christian Church, Grand Rapid: Eerdmans Publishing Company, 1958.

Shaw, Mark., Sepuluh Pemikiran Besar dari Sejarah Gereja., Surabaya: Momentum, 2003

Tong, Stephen., Reformasi dan Teologi Reformed. Jakarta : LRII, 1994

Urban, Linwood., Sejarah Ringkas Pemikiran Kristen., Jakarta: BPK GM, 2003

Wellem, F. D., Riwayat Hidup Singkat Tokoh-Tokoh Dalam Sejarah Gereja, Jakarta : BPK $\mathrm{GM}$

Yeniretnowati, T. A., \& Angin, Y. H. P. (2021). Peran Parenting Orangtua Dalam Perspektif Pendidikan Kristen di Era Digital. Harati: Jurnal Pendidikan Kristen, 1(1), 34-53. 